\title{
KS. WOJCIECH NECEL SCHR
}

Wydział Prawa Kanonicznego

Uniwersytetu Kardynała Stefana Wyszyńskiego w Warszawie

\section{DUSZPASTERSTWO LOTNICTWA CYWILNEGO. WSKAZANIA PASTORALNO-KANONICZNE}

Treść: Wprowadzenie. - 1. Korzystający z Duszpasterstwa Lotnictwa Cywilnego. - 2. Odpowiedzialność biskupa diecezjalnego za duszpasterstwo na cywilnych lotniskach. - 3. Kapelan portu lotniczego i jego współpracownicy. - 4. Struktury Duszpasterstwa Lotnictwa Cywilnego. - 5. Kaplica portu lotniczego. - 5.1. Kaplica katolicka. - 5.2. Kaplica chrześcijańska międzywyznaniowa. - 5.3. Kaplica międzyreligijna. - Zakończenie.

\section{Wprowadzenie}

XVI Międzynarodowe Seminarium Kapelanów Katolickiego Duszpasterstwa Lotnictwa Cywilnego odbyło się w czerwcu 2015 roku w Rzymie ${ }^{1}$. Refleksja prowadzona pod kierunkiem kard. A. M. Vegliò, przewodniczącego Papieskiej Rady ds. Duszpasterstwa Migrantów i Podróżujących koncentrowała się wokół tematu: „Evangelim Gaudium" - what suport for the pastoral care of airport chaplaincy? Otwierając spotkanie Gospodarz wskazał nadal obowiązujący charakter Wytycznych dla Katolickiego Duszpasterstwa Lotnictwa Cywilnego ${ }^{2}$

\footnotetext{
${ }^{1}$ Zob. Z. Stefaniak, Capellania dell'aeroporto "Chopin" a Varsavia, People on the Move 45(2015) nr 123 suppl., s. 95-98.

2 Pontificio Consiglio della Pastorale Per i Migranti e gli Itineranti, Direttive per la Pastorale Cattolica dell'Aviazione Civile, Città del Vaticano 1995. Dokument ten w j. polskim zamieszczony jest pod tytułem: Wytyczne dla Katolickiego Duszpasterstwa Lotnictwa Cywilnego w People on the Move 45(2015) nr 123 suppl., s. 237-248 (dalej WdKDLC).
} 
oraz na konieczność ich stosowania we współczesnych warunkach pracy cywilnych portów lotniczych ${ }^{3}$. Przypomniał również określone w Wytycznych i wciąż obowiązujące trzy zasadnicze wymiary posługi kapelanów cywilnych portów lotniczych. Obecność kapelana lotniska i jego asystentów ${ }^{4}$, świadectwo ich posługi ${ }^{5}$ oraz proklamacja Ewangelii ${ }^{6}$ to podstawowe elementy posługi duszpasterskiej na lotniskach.

W seminarium wzięło udział około 100 kapelanów lotnisk cywilnych z ponad 20 krajów Afryki, obu Ameryk, Azji i Europy. Papież Franciszek na specjalnej audiencji przyjął wszystkich zebranych i skierował do nich słowo zachęty do gorliwego podejmowania powierzonych zadaniach duszpasterskich i do wierności zasadom wskazanym w Wytycznych, przy jednoczesnym poszukiwaniu nowych rozwiązań?

\section{Korzystający z Duszpasterstwa Lotnictwa Cywilnego}

We wstępie do Wytycznych dla Katolickiego Duszpasterstwa Lotnictwa Cywilnego ówczesny przewodniczący Papieskiej Rady ds. Duszpasterstwa Migrantów i Podróżujących, abp. G. Cheli, w oparciu

${ }^{3}$ A.M. Vegliò, Discorso di benvenuto, People on the Move 45(2015) nr 123 suppl., s. 31-34.

${ }^{4}$ WdKDLC art. 15: „Obecność na lotnisku jest warunkiem świadczenia o Chrystusie i głoszenia Chrystusa w tym środowisku (...), obecność i dostępność (...) może być (...) niepowtarzalną szansą na spotkanie z Bogiem”.

${ }^{5}$ Tamże, art. 12: „Jeśli Duszpasterstwo Lotnictwa Cywilnego ma nieść Chrystusa do wszystkich ludzi i być zaczynem we wspólnocie portu lotniczego, to musi obejmować życie, problemy i konkretne sytuacje środowiska, w którym działa”; por. Konstytucja duszpasterska o Kościele w świecie współczesnym Gaudium et spes, nr 40 .

${ }^{6}$ Tamże, art. 14 b: „Ponieważ chrześcijanie zaangażowani w Duszpasterstwo Lotnictwa Cywilnego starają się świadczyć o Chrystusie swoim życiem, dlatego powinni głosić Dobrą Nowinę posługując się słowem mówionym i pisanym oraz wszystkimi innymi środkami proponowanymi przez nowoczesną technikę komunikacji”.

${ }^{7}$ Discorso di Sua Santità Papa Francesco ai partecipanti al Seminario Mondiale dei Cappelani Cattolici dell'Aviazione Civile, promosso dal Ponteficio Consiglio della Pastorale per i Migranti e gli Itineranti, People on the Move 45(2015) nr 123 suppl., s. 17-18. 
o nauczanie Soboru Watykańskiego II $^{8}$ wskazał, że posługa duszpasterska na lotniskach cywilnych ,jest ramieniem Kościoła rozciągającym się nad tymi, którzy nie mogą korzystać z normalnej opieki w parafiach ze względu na wykonywany zawód związany z liniami lotniczymi, bądź z lotniskami" "

Duszpasterstwo Lotnictwa Cywilnego „skierowane jest przede wszystkim do członków załóg samolotów”, a także do lotników przechodzących szkolenia, do członków personelu naziemnego, pracowników portów lotniczych oraz wszystkich działów usług portu lotniczego ${ }^{10}$ a także do ich rodzin ${ }^{11}$ oraz tych, „którzy wiele lat swojego życia poświęcili służbowo na tym polu, a obecnie są emerytami”"12.

W razie konieczności duszpasterstwo lotnisk adresowane jest także do pasażerów oraz „do szczególnych kategorii osób, takich jak uchodźcy przebywający na lotnisku w centrach odosobnienia, osoby w potrzebie, bezdomnych znajdujących schronienie w porcie lotniczym, itp.”'13, a także „najbiedniejszych i nieuprzywilejowanych, cierpiących lub innych znajdujących się na marginesie społeczeństwa"14 obecnych na lotnisku i to niezależnie od narodowości, wyznania, religii lub kultury.

\section{Odpowiedzialność biskupa diecezjalnego za duszpasterstwo na cywilnych lotniskach}

We wstępie do omawianej instrukcji abp. G. Cheli określił również zakres posługi, jaką „Kościół Katolicki pragnie spełniać na polu lotnictwa cywilnego" i wskazał, że Wytyczne, jako kanoniczno-duszpasterski dokument, skierowane są „do katolickich kapelanów

\footnotetext{
${ }^{8}$ Dekret o pasterskiej posłudze biskupów Christus Dominus, nr 18.

${ }^{9}$ G. Cheli, Wprowadzenie, w: WdKDLC s. 237; por. WdKDLC art. 5-8.

${ }^{10}$ WdKDLC art. 5.

${ }^{11} \mathrm{~J}$. Kalathiparambil, How to implement the apostolic exortation „Evangelii Gaudium" in the Pastoral Activities of Civil Aviation, People on the Move 45(2015) suppl. nr 123, s. 46.

${ }^{12}$ WdKDLC art. 6.

13 Tamże, art. 5 .

14 Tamże, art. 8 .
} 
lotnictwa cywilnego, pełniących funkcje duszpasterskie oraz do ich współpracowników"15. Z treści omawianego dokumentu wynika jednak, że Wytyczne dla Katolickiego Duszpasterstwa Lotnictwa Cywilnego Papieskiej Rady ds. Duszpasterstwa Migrantów i Podróżujących są w pierwszym rzędzie skierowane do biskupów diecezjalnych, na terenie których znajdują się cywilne porty lotnicze.

Według Wytycznych to biskup diecezjalny, na terenie którego diecezji znajduje się lotnisko cywilne, jest odpowiedzialny za duszpasterstwo na tym lotnisku oraz za włączenie prowadzonego tam apostolstwa w plan duszpasterski diecezji ${ }^{16}$. Swoje zadanie biskup sprawuje między innymi poprzez „wybór właściwej struktury duszpasterskiej dla apostolatu lotnictwa cywilnego (...) tak, by odpowiadała ona specyfice i potrzebom danego lotniska i wspólnoty lotnictwa cywilnego"17. Zaproponowana przez biskupa struktura winna być „integralną częścią życia Kościoła lokalnego”18, a także „dyspozycyjnym narzędziem we wspólnych działaniach, których kierunek leży w gestii ordynariusza diecezji”'19. Do niego też należy obowiązek mianowania kapelanów lotnisk oraz „wspierania ich i innych osób zaangażowanych w tym duszpasterstwie" ${ }^{20}$. On też odpowiada za przygotowanie pastoralne i duchowe duszpasterzy na lotniskach i za ich formację w czasie pełnienia posługi ${ }^{21}$.

W przypadku, gdyby port lotniczy znajdował się na terenie więcej niż jednej diecezji, prowadzona na nim opieka duszpasterska winna być przedmiotem uzgodnień pomiędzy zainteresowanymi biskupami diecezjalnymi ${ }^{22}$. Według Wytycznych prowadzone apostolstwo lotnictwa cywilnego winno być również przedmiotem troski odpowiednich Komisji Episkopatu danego kraju, a monitorowanie

\footnotetext{
15 Tamże.

${ }^{16}$ WdKDLC 38 b.

17 WdKDLC 37.

18 Tamże, art. 38 a.

${ }^{19}$ Tamże; por. Kodeks Prawa Kanonicznego (dalej KPK), kan. 381.

${ }^{20}$ WdKDLC 38 b.

${ }^{21}$ Tamże.

22 Tamże, art. 39.
} 
duszpasterstwa lotnictwa cywilnego w skali ogólnoświatowej należy do Papieskiej Rady ds. Duszpasterstwa Migrantów i Podróżujących $^{23}$, a od 1 stycznia 2017 r. do Dykasterii ds. Integralnego Rozwoju człowieka ${ }^{24}$.

\section{Kapelan portu lotniczego i jego współpracownicy}

Według omawianych Wytycznych członkami katolickiej kapelanii portu lotniczego oprócz kapelana, kapelanów pomocniczych i asystentów, są „pracownicy duszpasterstwa, pracownicy socjalni, pracownicy biura kapelanii oraz inni pomocnicy"25. Zdaniem Papieskiej Rady „wszyscy członkowie kapelanii lotnictwa cywilnego muszą być znani ze swej uczciwości i troski o osoby powierzone ich pieczy". Oprócz specjalistycznego przygotowania pastoralnego i wymogów moralnych „wskazana jest również znajomość języków obcych, a biegłość w języku angielskim jest niezbędna”26.

Według Kodeksu Prawa Kanonicznego Kościoła łacińskiego ${ }^{27}$ „kapelanem jest kapłan, któremu powierza się przynajmniej częściowo stałą troskę pasterską o jakąś wspólnotę lub specjalny zespół wiernych, wykonywaną zgodnie z postanowieniami prawa powszechnego lub partykularnego” 28 . Duszpasterz, „któremu powierzona została stała opieka duszpasterska nad wyznawcami wiary katolickiej w środowisku lotnictwa cywilnego", nosi tytuł kapelana lotnictwa cywilnego ${ }^{29}$. Może on być kapłanem diecezjalnym lub zakonnym, albo przynależeć do stowarzyszenia życia apostolskiego. Jako kapłan zakonny albo przynależący do stowarzyszenia w czasie pełnienia obowiązków kapelana, pozostaje inkardynowanym do swojej wspólnoty, a w zakresie

\footnotetext{
${ }^{23}$ Tamże, art. 40; por. W. NeCEL, Kuria Rzymska wobec dobra duchowego migrujacych, Prawo Kanoniczne 56(2013) nr 1, s. 47-71.

${ }^{24}$ Fr AnCISzeK, Motu proprio ustanawiajace Dykasterię ds. Integralnego Rozwoju Człowieka z 17.08.2016r.

${ }^{25}$ Tamże, art. 44.

${ }^{26}$ Tamże, art. 51.

${ }^{27}$ Kodeks Prawa Kanonicznego z 1983 r. (dalej KPK).

${ }^{28}$ KPK kan. 564.

${ }^{29}$ WdKDLC art. 45a.
} 
obowiązków duszpasterskich i dyscypliny podlega ordynariuszowi diecezji, na terenie której znajduje się lotnisko.

W każdym przypadku kapelan jest mianowany przez biskupa diecezjalnego, na terenie którego się znajduje powierzona mu kapelania $^{30}$ i posiada taki sam status $\mathrm{w}$ diecezji, jak i inni kapłani ${ }^{31}$. Celem owocnej posługi kapelan lotniska „winien być wyposażony we wszystkie uprawnienia, których wymaga właściwe sprawowanie troski pasterskiej”32. Na mocy swego urzędu „oprócz tego, co przyznaje kapelanowi prawo partykularne lub specjalna delegacja, posiada on (...) władzę spowiadania wiernych powierzonych jego pieczy, a także głoszenia im słowa Bożego, udzielania Wiatyku i namaszczania chorych oraz udzielanie sakramentu bierzmowania tym, którzy znajdują się w niebezpieczeństwie śmierci"33. Dla jakości posługi kapelana lotnictwa cywilnego istotna jest współpraca nie tylko z innymi pracownikami kapelanii, ale również z proboszczem lub proboszczami parafii, na terenie którego bądź których znajduje się lotnisko ${ }^{34}$.

W swojej posłudze kapelan lotnictwa cywilnego może być wspierany przez kapelana pomocnika lub asystenta, mianowanego przez miejscowego ordynariusza ${ }^{35}$. Rytm życia w cywilnych portach lotniczych sprawia, że w posłudze Duszpasterstwa Lotnictwa Cywilnego ważną rolę spełniają współpracownicy kapelana zwani asystentami socjalnymi oraz asystenci biura kapelanii. Asystentem socjalnym kapelana, może być zarówno osoba duchowna jak i świecka; niekoniecznie musi być nim katolik ${ }^{36}$. Obszar posługi wyznaczają między innymi różnego rodzaju potrzeby osób korzystających z lotnisk, a szczególnie ubogich, zagubionych i chorych ${ }^{37}$. Jeżeli duszpasterstwo lotnictwa cywilnego określi się słowami: obecność, świadectwo i proklamacja,

\footnotetext{
${ }^{30}$ KPK kan. 565.

${ }^{31}$ WdKDLC art. 45 a.

${ }^{32}$ Tamże, art. 45 b; por. KPK kan. 565.

${ }^{33}$ KPK kan. 566 par. 1; WdKDLC art. 45b.

${ }^{34}$ WdKDLC art. 45c.

${ }^{35}$ Por. Tamże, art. 46.

${ }^{36}$ Por. Tamże, art. 48.

${ }^{37}$ Tamże.
} 
to zauważa się jednocześnie zadania, jakie stają przed biurem kapelana portu lotniczego. W biurze tym pracują przygotowani asystenci, których zadaniem jest publikacja materiałów duszpasterskich, prowadzenie archiwum, praca w recepcji i w sekretariacie lotnictwa ${ }^{38}$. Ze względu na specyfikę posługi pracowników Duszpasterstwa Lotnictwa Cywilnego omawiane Wytyczne proponują, by do tych posług zatrudniać „emerytowany personel lotnictwa, który zna środowisko i dysponuje większą ilością czasu"39.

Zadania stawiane kapelanowi oraz pozostałym pracownikom Duszpasterstwa Lotnictwa Cywilnego wymagają przygotowania osób kierowanych do tej specyficznej formy działalności. Odpowiednią formację winni przejść także wolontariusze Duszpasterstwa ${ }^{40} . \mathrm{Z}$ tą formą apostolatu w kontekście duszpasterstwa ludzi mobilnych winni zapoznać się wszyscy przygotowujący się do przyjęcia święceń diakonatu i prezbiteriatu ${ }^{41}$. Przygotowanie teoretyczne winno iść w parze z przygotowaniem praktycznym, a nowo mianowani kapelani winni przynajmniej przez trzy miesiące swoją posługę spełniać „u boku kapelana odchodzącego" ${ }^{42}$. Przygotowanie pozostałych pracowników duszpasterstwa oraz współpracowników socjalnych winno dotyczyć „prawdziwego znaczenia i wartości dóbr doczesnych zarówno samych w sobie, jak i w odniesieniu do wszystkich celów osoby ludzkiej”, a także praktycznego docierania w portach lotniczych do osób potrzebujących ${ }^{43}$.

Dla jakości apostolatu cywilnych portów lotniczych ważne jest nie tylko uprzedzające przygotowanie kapelanów i pozostałych pracowników Duszpasterstwa Lotnictwa Cywilnego, ale również kontynuacja tego przygotowania poprzez różne formy stałej formacji

\footnotetext{
${ }^{38}$ Tamże, art. 49.

39 Tamże, art. 50.

${ }^{40}$ Por. Tamże, art. 59-60.

${ }^{41}$ Tamże, art. 56.

${ }^{42}$ Tamże, art. 57-58.

${ }^{43}$ Tamże, art. 60; por. Dekret o apostolstwie świeckich Apostolicam actuositatem, nr 31 .
} 
duchowej i pastoralnej ${ }^{44}$. Oprócz wskazanych w Wytycznych rekolekcjach i dniach skupienia, w formacji tej istotne są pielgrzymki oraz kursy „we wszystkich dziedzinach nauki Kościoła” ${ }^{45}$. W formacji stałej kapelanów portów lotniczych i ich współpracowników owocne jest uczestnictwo w międzynarodowych seminariach organizowanych przez Sekcję ds. Apostolstwa Lotnictwa Cywilnego Papieskiej Rady ds. Duszpasterstwa Migrantów i Podróżujących oraz w Światowych Kongresach Duszpasterstwa Lotnictwa Cywilnego ${ }^{46}$. Odpowiedzialnym za formację kapelanów lotnisk oraz ich asystentów jest miejscowy biskup ordynariusz ${ }^{47}$.

Gdyby zabrakło kapłana, który mógłby pełnić posługę kapelana lotniska, biskup ordynariusz miejsca może również skierować do tej posługi, według potrzeb, diakona stałego, a także zakonnicę lub zakonnika, a nawet osobę świecką pełniącą już tę posługę lub będącą już pracownikiem ${ }^{48} \mathrm{w}$ duszpasterstwie lotnictwa cywilnego ${ }^{49}$. Do ich zadań należy w szczególności wypełnianie określonych zadań duszpasterskich oraz niesienie wielorakiej pomocy socjalnej i prawnej potrzebującym ${ }^{50}$.

\section{Struktury Duszpasterstwa Lotnictwa Cywilnego}

Biskup diecezjalny oprócz tego, że odpowiada za przygotowanie teologiczno-pastoralne kapelanów cywilnych portów lotniczych i osób wspierających ich działalność apostolską oraz za ich właściwy dobór, winien również troszczyć się o adekwatne struktury dla tej

${ }^{44}$ WdKDLC art. 52-54.

45 Tamże, art. $54 \mathrm{~d}$.

${ }^{46}$ Tamże, art. 62-63.

${ }^{47}$ Tamże, art. 38 b.

${ }^{48}$ Tamże, art. $47 \mathrm{a}$.

49 Tamże, art. 47c.

${ }^{50}$ Tamże, art. 47b: „Pracownik wypełnia następujące czynności duszpasterskie: służy podczas liturgii, głosi słowo Boże w formie katechezy, wyjaśnia i broni wartości chrześcijańskich oraz wskazuje ich właściwe zastosowanie w życiu wobec problemów naszych czasów, realizując przy tym uczynki miłosierdzia względem duszy i ciała”. 
formy apostolatu w swojej diecezji, by odpowiadały one „specyfice i potrzebom danego lotniska i wspólnoty lotnictwa cywilnego"51. Struktury te winny być „,integralną częścią życia Kocioła lokalnego" oraz miejscowych wspólnot parafialnych.

Omawiane Wytyczne wśród struktur Duszpasterskich Lotnictwa Cywilnego wskazują na missio cum cura animarum $^{53}$, a więc misję duszpasterską włączoną w struktury parafii terytorialnej. Przynależność do tak powołanej przez biskupa ordynariusza misji wymaga od wiernych spełnienia kryteriów, które powodowały powstanie misji. Prowadzący misję duszpasterz, jako kapelan portu lotniczego swoją opieką obejmuje wszystkich pracowników portów lotniczych i linii lotniczych oraz członków ich rodzin, a także korzystających z lotnisk. Duszpasterz misji przez cały okres pełnienia posługi podlega właściwemu biskupowi diecezjalnemu w zakresie prowadzonej działalności duszpasterskiej i zachowania dyscypliny kościelnej. Kierujący misją winien być wyposażony we wszystkie uprawnienia, właściwe do sprawowania troski pasterskiej. Zgodnie z prawem może mu przysługiwać prawo asystowania przy zawieraniu małżeństw, pod warunkiem, że jedna ze stron spełnia warunki przynależności do misji. On też zgodnie z dyspozycjami prawa powszechnego i partykularnego ma obowiązek prowadzenia ksiąg parafialnych, których kopie raz w roku przesyła do proboszcza miejscowej wspólnoty parafialnej. Posługę swą

\footnotetext{
${ }^{51}$ WdKDLC art. 37.

${ }^{52}$ Tamże, art. 38a.

${ }^{53}$ Kongregacja Biskupów, Instrukcja Ecclesiae imago, w: Ustrój hierarchiczny Kościoła. Wybór źródeł (red. M. Sitarz, W. Kacprzak), Lublin 2006, nr 183: „Przez misję duszpasterską rozumie się tutaj urząd kościelny, na mocy którego zostaje powierzona na czas określony przez biskupa jakiemuś prezbiterowi nie proboszczowi władza prowadzenia duszpasterstwa - i to tak, jakby był proboszczem - w jakimś oznaczonym miejscu, należącym do prawdziwej parafii, której jednak proboszcz nie może tej określonej grupy wiernych objąć dostatecznym posługiwaniem. Celem uniknięcia niepotrzebnych nieporozumień, niech biskup ustali wszystko dokładnie na piśmie, wysłuchawszy zdania zainteresowanego proboszcza”.
} 
sprawuje w oparciu o przyznaną kaplicę, w których może swobodnie sprawować posługę duszpasterską wobec powierzonych wiernych ${ }^{54}$.

Wytyczne wskazują również na inną strukturę właściwą dla duszpasterstwa w portach lotniczych. Po rozeznaniu sytuacji biskup ordynariusz dla tych wiernych, „którzy ze względu na warunki życia nie mogą korzystać ze zwyczajnej posługi proboszczów"55, może erygować kapelanię portu lotniczego ${ }^{56}$. Duszpasterz prowadzący kapelanię na mocy prawa powszechnego „winien być wyposażony we wszystkie uprawnienia, których wymaga właściwe sprawowanie troski pasterskiej”"57, a swoją działalność prowadzi w ścisłej zależności od miejscowej parafii i w oparciu o jej biuro parafialne.

Omawiany dokument bierze również pod uwagę sytuację, kiedy brakuje prezbitera do posługi duszpasterskiej w kapelanii lotniska. Wówczas biskup diecezjalny może powierzyć pracę w Duszpasterstwie Lotnictwa Cywilnego diakonowi stałemu albo innej osobie zakonnej lub świeckiej. Może to być zarówno kobieta jak i mężczyzna. "Nie mogą oni jednak sprawować funkcji właściwych kapłanom”58.

\section{Kaplica portu lotniczego}

Swoją posługę duszpasterską kapelan portu lotniczego sprawuje w oparciu o kaplicę, która jest „duchowym centrum lotniska, gdzie Chrystus przemawia w ciszy serca do człowieka" ${ }^{29}$. Wytyczne podkreślają, że winna być ona łatwo dostępna i dobrze oznakowana. Omawiany dokument zwraca uwagę, że przy organizacji kaplicy należy zadbać o zachowanie niezbędnych na lotnisku norm bezpieczeństwa ${ }^{60}$.

\footnotetext{
${ }^{54}$ Por. Papieska Rada ds. Duszpasterstwa Migrantów i Podróżujących, Instrukcja Erga migrantes caritas Christi, art. 7 par 2; art. 7 par. 3; art. 8 par. 1; art. 10.

${ }^{55}$ KPK kan. 568.

${ }^{56}$ WdKDLC art. 42.

${ }^{57}$ KPK kan. 566.

${ }^{58}$ WdKDLC art. 43; por. KPK kan. 230 par. 1.

${ }^{59}$ Tamże, art. 16.

${ }^{60}$ Tamże, art. 24: „Idealną lokalizacją byłaby przestrzeń pomiędzy strefą powszechnego dostępu a strefą, w której przebywają osoby po odprawie paszportowo-celnej, z wejściem z obu stron. Oczywiście ze względów bezpieczeństwa powinny
} 


\subsection{Kaplica katolicka}

Kodeks prawa Kościoła łacińskiego wskazuje, że kaplica jako kościół „jest budowlą świętą przeznaczoną dla kultu Bożego, do której wierni mają prawo wstępu w celu wykonywania w niej kultu, zwłaszcza publicznego" ${ }^{61}$. Kaplica w porcie lotniczym może być wykorzystywana do innych celów. Trzeba jednak pamiętać, że „w miejscach świętych dopuszcza się tylko to, co służy sprawowaniu i szerzeniu kultu, pobożności i religii”" 2 . Ordynariusz miejsca „może przejściowo zezwolić na użycie (kaplicy) do innych celów, jednakże nie przeciwnych świętości miejsca"63.

W kaplicy katolickiej portu lotniczego winien być przechowywany Najświętszy Sakrament. Zgodnie z wymogami prawa kanonicznego ${ }^{64}$ należy zadbać o godne miejsce dla umieszczenia tabernakulum, o zabezpieczenie przed profanacją oraz o możliwość adoracji Chrystusa obecnego pod postacią chleba ${ }^{65}$. Dla organizacji posługi duszpasterskiej w portach lotniczych ważny jest wymóg Wytycznych, by w kaplicach, w których „przechowywany jest Najświętszy Sakrament, zawsze musi być ktoś mający nad nią pieczę, a kapłan powinien tam odprawić wedle możliwości Mszę świętą przynajmniej dwa razy w miesiącu"66.

\subsection{Kaplica chrześcijańska międzywyznaniowa}

Zazwyczaj „w porcie lotniczym każdy z Kościołów i każda wspólnota kościelna otacza opieką duszpasterską swoich członków" ${ }^{67}$. Jednak ze względu na organizację obsługi pasażerów i dobro duchowe obsługi lotniska, w portach lotniczych nie zawsze można zorganizować kaplicę tylko dla katolików. W to miejsce są organizowane kaplice

pozostać podjęte odpowiednie środki ostrożności, na przykład strefy mogą być oddzielone ścianą z nietłukącego się szkła”.

${ }^{61}$ KPK kan. 1214; por. WdKDLC art. 17.

${ }^{62}$ KPK kan. 1210.

${ }^{63}$ Tamże.

${ }^{64}$ Por. Tamże, kan. 938 par. 2-3.

${ }^{65}$ WdKDLC art. 19 a-b.

${ }^{66}$ Tamże, art. 19 c.

${ }^{67}$ Tamże, art. 7. 
do wszystkich Kościołów i Wspólnot chrześcijańskich, obecnych w porcie lotniczym. Celem zapewnienia wzajemnego poszanowania, tradycji i doktryny, wspólne korzystanie z takiej kaplicy powinno być poprzedzone należytymi konsultacjami ze zwierzchnikami poszczególnych Kościołów i Wspólnot ${ }^{68}$. Korzystający z tych kaplic winni okazywać wobec siebie nawzajem należyty szacunek. Winni również szanować normy liturgiczne i sakramentalne innych Kościołów i Wspólnot ${ }^{69}$.

Kaplica międzywyznaniowa jest dla chrześcijan różnych Kościołów i Wspólnot uprzywilejowanym miejscem spotkania, modlitwy i dialogu ekumenicznego ${ }^{70}$. Stąd zarówno katolicki kapelan lotniska jak i jego współpracownicy powinni posiadać dostateczną wiedzę o normach dialogu oraz o specyficznych potrzebach duchowych i sakramentalnych wiernych chrześcijan niekatolików ${ }^{71}$. Ze względu na dobro wiernych korzystających $z$ tego typu kaplic, ważna jest znajomość i przestrzeganie dyspozycji kan. 844 KPK dotyczących communicatio in sacris ${ }^{72}$.

Świadectwo o Chrystusie jest jednym z wyznaczników duszpasterstwa katolickiego na lotniskach cywilnych i dlatego omawiane Wytyczne zalecają kapelanom i ich asystentom „współpracę z osobami prowadzącymi działalność duszpasterską z ramienia innych Kościołów i Wspólnot kościelnych"73.

\subsection{Kaplica międzyreligijna}

Papieska Rada ds. Duszpasterstwa Migrantów i Podróżujących wskazuje również, że tam, gdzie jest to możliwe, oprócz kaplicy katolickiej i międzywyznaniowej można w portach lotniczych tworzyć kaplice międzyreligijne. W znaczeniu kanonicznym kaplica ta nie jest

\footnotetext{
${ }^{68}$ Tamże, art. 20.

${ }^{69}$ Tamże.

${ }^{70}$ Por. J. Kalathiparambil, dz. cyt., s. 48.

${ }^{71}$ WdKDLC art. 61.

${ }^{72}$ Por. KPK kan. 844 par. 1-5.

${ }^{73}$ WdKDLC art. 13.
} 


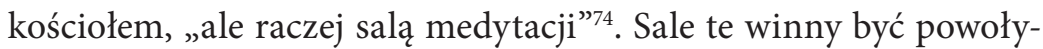
wane po konsultacji z przedstawicielami zainteresowanych wyznań i religii ${ }^{75}$.

Gdyby w porcie lotniczym była tylko kaplica międzyreligijna, wówczas „należy zadbać, aby znalazł się w niej przenośny ołtarz do celebracji Eucharystii”, a wszystkie „inne paramenty liturgiczne potrzebne do celebracji mogą być przechowywane w sąsiednim pokoju, służącym jako zakrystia"76. Zgodnie z prawem kanonicznym w takiej kaplicy nie może być przechowywany Najświętszy Sakrament ${ }^{77}$.

Kaplica międzyreligijna winna być miejscem wzajemnego szacunku i tolerancji wiernych poszczególnych wyznań i religii. Jest ona doskonałą okazją do prowadzenia autentycznego dialogu międzyreligijnego opartego o podstawowe wartości ${ }^{78}$. Zaangażowani $\mathrm{w}$ apostolat Duszpasterstwa Lotnictwa Cywilnego „powinni posiadać odpowiednią wiedzę (...) o innych religiach oraz o specyficznych potrzebach ich wyznawców"79, a analizowane Wytyczne wskazują dodatkowo na konieczną na lotniskach „współpracę z wyznawcami innych religii i wszystkimi ludźmi dobrej woli" ${ }^{\text {. }}$.

\section{Zakończenie}

Omawiany dokument jest wyrazem troski Kościoła o wiernych w ich konkretnych sytuacjach życiowych i zawodowych. Wskazania kanoniczno-duszpasterskie zawarte w Wytycznych mają na celu określenie osób, do których Duszpasterstwo Lotnictwa cywilnego jest skierowane, a także wskazać odpowiedzialnych za tego rodzaju posługę duszpasterską. Mają również określić konieczne struktury służące tej formie działalności. Według Wytycznych istotnym elementem działalności duszpasterskiej, tak na lotniskach krajowych jak

\footnotetext{
${ }^{74}$ Tamże, art. 22.

75 Tamże.

${ }^{76}$ Tamże, art. 23a.

${ }^{77}$ KPK kan. 934 par. 1.

${ }^{78}$ Por. J. Kalathiparambil, dz. cyt., s. 49-50.

${ }^{79}$ WdKDLC art. 61.

${ }^{80}$ Tamże, art. 13.
} 
i międzynarodowych, jest otwarcie się na tych, do których ta forma apostolatu jest kierowana oraz na wszystkich potrzebujących pomocy a przebywających na terenie portu lotniczego.

\section{Pastoral care of Civil Aviation. Pastoral recommendations}

The document in question (Catholic Civil Aviation Pastoral Directives) is an expression of care the Church has for the faithful in their specific life and professional situations. The canonical and pastoral indications contained in the Directives are intended to identify the persons to whom the Civil Aviation Ministry is directed as well as those responsible for this kind of pastoral care, and indicate the necessary structures for this form of apostolic activity. According to the guidelines an important element of this pastoral care, so at domestic as well as international airports, is to open itself to those to whom this form of apostolate is directed and to all those in need of help while staying at the airport.

SŁOWA KLUCzowE: cywilny port lotniczy; kapelan; asystent kapelana; kaplica; obecność; świadectwo; głoszenie ewangelii; odpowiedzialność duszpasterska; struktury duszpasterskie

KEYwORDS: civil airport; chaplain; assistant to the chaplain; chapel; presence; testimony; proclamation of the gospel; pastoral responsibility; pastoral structures

\section{Nota o Autorze:}

Ks. DR HAB. WOJCIECH NeCEL SCHR, PROF. UKSW - profesor nadzwyczajny na Wydziale Prawa Kanonicznego UKSW w Warszawie, kierownik zakładu Historii Źródeł i Literatury Prawa Kanonicznego w katedrze Historii Prawa Kanonicznego. 